\title{
Electronic Banking Strategies and Their Impact on Customers' Satisfaction: Empirical Evidence from Palestine
}

\author{
Mohammad Sharif Sulaiman ${ }^{1} \&$ Naser AbdelKarim ${ }^{2}$ \\ ${ }^{1}$ Ramallah, Palestine \\ ${ }^{2}$ Arab American University, Palestine \\ Correspondence: Mohammad Sharif Sulaiman. E-mail: Mohsul2@gmail.com
}

Received: August 24, 2019

doi:10.5539/ass.v15n10p20

\begin{abstract}
Digital banking could be a new era for banks in Palestine. Electronic banking services have become an essential part of the banking services in most of the banks in Palestine, along with the traditional banking represented by the physical branches. Recently, more banks in Palestine have shifted towards Electronic Banking services by utilizing the advancement in the Information and Telecommunication technology thereby enhancing the customer experience and satisfaction, and increasing the efficiency of the banking services, since electronic banking is available 24/7, with no restrictions on working hours.
\end{abstract}

This study examines the correlation between electronic banking services in Palestine and customer satisfaction. The main question is: "What is the impact of the electronic banking strategies on customers'satisfaction within the banking sector in Palestine?" The methodology used to tackle this question is based on two major components: a) survey design targeting 347 banks' customers in 8 banks in Palestine, b) Direct interviews with the Top management of two major banks in Palestine (Arab Bank and Bank of Palestine) on the bank's future strategies towards Electronic banking.

With the introduction of the Third generation of wireless internet (3G) service in Palestine, the internet has become readily available and accessible, at any time. Along with the availability of traditional wireless network in the bank itself, the banking systems in Palestine are moving quickly toward digitalization. This study finds several interesting findings, one of these findings is the significant positive correlation between electronic banking strategies and customer satisfaction using these services. Thus, the study null hypothesis was rejected and the alternative hypothesis was accepted. This finding will be guiding the banks in Palestine to build strategies focusing on electronic banking services to achieve one of their top objectives by attracting and retaining their customers for the long-term.

Keywords: customer satisfaction, Electronic Banking (E-Banking), electronic banking strategies, Information and Telecommunication Technology (ITC), Palestine banking sector

\section{Introduction}

\subsection{General Overview}

Information and Communication Technology (ICT) is significantly transforming most businesses to become technologically friendly. Currently, we have reached the fourth stage of the Technology Revolution, which includes the automation of most processes in the sector of business, education, economy, etc. and rising new technologies such as the Internet of Things (IoT), Self-driving cars, etc. The Banking sector is no exception, as it is also undergoing profound transformation within its processes. Banking worldwide has shifted towards electronic banking which has been facilitated by advancements in technology, which varied from one country to another. Some banks moved completely from traditional banking to digital banking, others moved to digital banking while maintaining traditional banking as another option. However, in both options, the Internet access is essential for executing banking transactions, whereas the availability and the quality of Internet service will differ from one country to another, and from one bank to another.

Thulani et al. (2009): The term Electronic Banking "refers to systems and processes that enable customers to get access to their bank accounts and to receive information on products and services". Nowadays customers are able to access all bank services via the Internet. Thulani et al. (2009): "They do interact with banks without the 
intervention of or inconvenience of sending letters, faxes, original signatures, and telephone Conformations." According to Keivani et al. (2012), Electronic Banking is "an umbrella term for the process by which a customer may perform banking transactions electronically without visiting a brick-and-mortar institution".

Applying the Electronic Banking strategy contains two main elements: the customer's reliability in Electronic Banking, and is the electronic banking services itself, how safe and available in providing different banking solutions.

According to The Palestine Monetary Authority (2018): Palestine Banking sector has fourteen legal banks introducing the banking services in the West Bank and Gaza, 7 local banks and 7 foreign banks, most of them have started the move into electronic banking services side by side with the traditional banking, through the existing physical branches inside Palestine. The study found that all banks are offering Automatic Teller Machines (ATMs) and Internet banking, with approximately half of them offering mobile banking and others offering online banking side by side with existing physical branches network in the West Bank and Gaza.

One of the strategic goals of banks is to attract new customers and retain the existing as much as possible. The key to achieving that is the trust relationship between the banks and their customers since trust is one of the bank's most valuable assets. This directly impacts the bank's reputation, which is built over time through the customer's lifecycle with the bank. The more the customer is satisfied with the bank's services, the more he/she is satisfied with the bank, and vice versa.

\subsection{Problem Statement}

The main research question of this study is: "What is the impact of electronic banking strategies on customer satisfaction in Palestine?" This question will be investigated and answered from two perspectives: The first is from the perspective of banking customers themselves and how much they are satisfied with electronic banking (E-Banking). The second is from the perspective of the banks' administration and how they find the benefits for the banks in offering the E-banking services for their customers in terms of cost, operations efficiency, and customer relations perspectives.

This will act as a guide for banks to use if they intend to go over the electronic banking services, they will have to increase the investment in these electronic solutions when opening or expanding the physical bank branch. If they need to maintain the old fashion traditional banking method, since the customers in Palestine may still prefer visiting the banks and execute the banking transactions face to face with the bank's employees.

\subsection{Study Objectives}

The main objective is to fill the knowledge gap, due to the limited previous studies conducted on this subject in Palestine. This will be done by achieving the following sub-objectives:

- Examining the impact of Electronic Banking on customers' satisfaction by targeting the 14 banks working in Palestine, under the umbrella of Palestine Monetary Authority (PMA 2018).

- Developing a clear overview of the Banks' Management strategies and Plans towards Electronic Banking in Palestine, by conducting interviews with selective banks.

- Understanding the main factors, influencing customer satisfaction level toward Electronics Banking services, through the research design and questionnaire.

- Guiding all the key stakeholders (the banks, the Palestine Monetary Authority, and Palestine Government), in developing their future strategies, regarding the Electronic Banking services and financial services, for better coordination and better results for the end-users (Customers).

\subsection{Scope and Significance of the Study}

The scope of the study will be on the 14 banks working in Palestine (pma.ps 2018), and this will demonstrate the impacts of the banking sector, regardless to the differences in the service between the banks. The study is limited to four main electronic banking services, which are Automatic Teller Machine, Internet Banking, Phone Banking, and Mobile Banking. Others payments' services, payments' systems, and cards services were not covered in this study.

The significance of this study comes from different aspects:

- The study topic is arguable, due to the rise of digital banking systems and FinTech companies.

- The study focuses on two major issues in the banks, the first is the bank's services quality, availability, and cost-efficiency. The second is the customers. Fierce competition is pushing banks to improve the products and services and to create clever banking solutions for their customers. 
- The study combines two effective methodologies, interviews, and questionnaires. This will provide a better understanding of the subject from the banks' Management perspective and the customers' perspective.

- The study results are essential for all stakeholders which are: The Banks, PMA, Palestine Government, Global Regulators, and the Banks' customers.

\subsection{The Study Hypotheses}

Based on the study main question, and all the previous studies, the study has one main hypothesis and five sub-hypotheses, as follow:

- Main Hypothesis: to examine the correlation between customer satisfaction and Electronic Banking.

$\mathbf{H}_{\mathbf{0}}$ : There is no significant positive impact on customer satisfaction with Electronic Banking.

$\mathbf{H}_{1}$ : There is a significant positive impact on customer satisfaction with Electronic Banking.

- Sub-Hypotheses: to examine the correlation between the five main variables in research design and customer satisfaction.

$\mathbf{H}_{1-1}$ : Easy-to-use Electronic Banking has a significant positive effect on customer satisfaction.

$\mathbf{H}_{1-2}$ : Reliable Electronic Banking has a significant positive effect on customer satisfaction.

$\mathbf{H}_{1-3}$ : Electronic banking Information security and privacy have a significant positive effect on customer satisfaction.

$\mathbf{H}_{1-4}$ : Electronic banking cost and fees have a significant positive effect on customer satisfaction.

$\mathbf{H}_{1-5}$ : Electronic banking availability has a significant positive effect on customer satisfaction.

\section{Material Studied}

There are many international studies and researches that have examined the electronic banking services and customer satisfaction in banking sectors in many countries worldwide. Either in the developing or in the developed countries, this is an indicator of the importance of this issue, especially with the adoption of Electronic Banking services are increasing with time worldwide.

This chapter will examine two main concepts, which are Electronic Banking (E-Banking) and Customer Satisfaction (CS), the previous researches and studies and finally Palestine banking sector overview.

\subsection{Conceptual Framework}

In order to be able to understand and investigate the relationship between electronic banking (E-Banking) and the customer's satisfaction, the study will examine these two concepts separately:

Regarding the E-Banking, there are many numerous definitions provided by different studies, which are:

Raza et al. (2015) "E-banking allows customers to inquire information and carry out most banking services such as account balance inquiry, bill-payment and inter-account transfers through the internet"

AL-Zahrani (2015) defined the term "Electronic Banking" or "e-banking" as is remote banking services provided by authorized banks, or their representatives through devices operated either under the bank's direct control and management or under the outsourcing agreement.

Addai et al. (2015) E-Banking is giving the customer opportunities to access and use the banking services from their homes or offices instead of in the branches, and such access either from the personal computer of the mobile phones with an internet connection. In addition, E-banking enables the customer to do banking anywhere anytime available 24/7. Such as money transfer, bill payment and request a bank statement.

Al-Otaibi et al. (2018) Mobile banking (M-banking) is another form of electronic banking as of Internet banking (E-banking) that allows the customer to access the banking services anywhere anytime and execute financial transactions over the mobile network. The advanced in the smartphone and the widespread and grow during the last 20 years, support the adopting of (M-banking) by the customers. And Ovia (2005). Providing banking services to clients via the internet or mobile technology like the mobile phone, computers and the Automatic Teller Machines (ATM).

The study concludes the term electronic banking as the customer's ability to perform banking transactions directly through the internet or a network using a computer, Laptop, Tablet, smartphones or any fit device anywhere and anytime without the need to visit the bank's branch physically.

The other concept is customer satisfaction, which has been defined as follow: 
Yi. (2018) The customer satisfaction is the key concept of the new marketing by meeting the customer needs and expectations, and it became the strategic goal for the firms for surviving and growing. Customer satisfaction not only helps the firms to attract new customers but also retaining the existing customers.

Hill (2017) Also "customer satisfaction is a measure of how your organization's total product performs in relation to an asset of customer requirements. Explaining how to measure customer satisfaction in any industry and what affects the accuracy of those results. Indeed, there are two main factors; one of them is by asking the right questions, the other is asking the right people."

Oh (1999). "Service quality and customer value work together ad mediator toward the perception of customer satisfaction".

Kotler (2006) defined customer satisfaction, as "it's a person's feeling of pleasure or disappointment resulting from comparing a product's performance (outcome) in relation to his or her expectation and the customer is key in this judgment."

\subsection{Previous Researches and Studies}

In this section, the study will explain the previous related studies, results, and conclusions. The previous studies include many countries in different banking sectors, as follow:

AlHaliq (2016) examined customer satisfaction with electronic banking services in Saudi Arabia in AlQassim region inside Saudi Arabia. The study examined the electronic banking adoption and customer satisfaction based on three main pillars, Ease to use, information security and ability to control these services. The study concludes that the banks should focus on customer awareness towards electronic banking services and how to use. The banks also need to improve the efficiency of the electronic banking core system, by having more problem-solving to build the trust of customers towards the banks, and the banks need to enhance security for the customer to use electronic banking. In general, with full security and trust of the customer for electronic banking services, customer satisfaction will improve.

Addai et al. (2015) investigated the impact of electronic banking services delivered for customers in Ghana, "Banking gives customers the opportunity to access banking services from the comfort of their homes and offices and also be able to do most of the transactions which would have been done in the banking halls. With the use of personal computer (PC) or even mobile phone with an internet connection, customers are able to carry out transactions such as cash withdrawals, payments of utility bills, transfers from one account to the other, viewing and printing of statements as well as a request for checkbooks on their traditional accounts". The study aims are to evaluate the e-banking availability, convenience, and reliability and to find out the effect of e-banking services on customer satisfaction in the Ghanaian banking sector. The study analyzed the relationship between E-banking and customer satisfaction considering the three main dimensions, availability, reliability, and convenience. The study relied on primary and secondary data sources from three banks in Ghana (Trust Bank Ghana Limited, Ecobank Ghana Limited, and Barclays Bank Ghana Limited), up to 150-sample size. The SPSS analysis showed a strong positive correlation between customer satisfaction and E-banking availability, convenience, and reliability.

The study also analyzed primary data using regression analysis, by creating a model to measure the customer satisfaction level considering three main independent variables: convenient, availability and reliability of E-banking. It showed $72.5 \%$ of the dependent variable explained by independent variables. The regression model enabling the banks to improve customer satisfaction by enhancing the E-banking availability, convenience, and reliability by a specific percentage. In sum and based on the analyzed data. Most banks in the world, especially the developed countries are moving towards electronic banking services. In the Ghanaian banking sector, "it is evident that improved e-banking service delivery enhanced customer satisfaction."

Raza et al. (2015) examined the relationship between the internet banking and customer satisfaction in Pakistan by using the service quality dimensions (SERVQUAL) model. The primary data collected from 400 users from the questionnaire included 30 items. The five factors were Assurance, Empathy, Reliability, Responsiveness, and Tangibility, all to measure customer satisfaction. Based on the regression analysis the results show that tangibility, reliability, responsiveness, and assurance had a significant positive impact on customer satisfaction but empathy had a positive impact but not significant. The study recommended to enhance the internet banking platform and to improve the security to online banks usage, in additions of including more services in this channel and continuous improvements. This will increase the customers' comfort and confidence, also improve quality.

Ahmad (2011) investigated the impact of e-banking on the outcome of customer satisfaction in Jordanian 
commercial banks in Jordan, which includes 24 commercial banks. In order to know the factor may be influenced by the adoption level by the customers and how the customer satisfaction effect on the loyalty and Word-of-Mouth (WOM). The study took into consideration: accessibility, convenience, security, privacy, content, design, speed, fees, and charges that may have an influence on customer satisfaction. A multiple regression model approach applied on primary data collected from 179 correctly completed questionnaires. The model considered customer satisfaction as a dependent variable and all other nine factors are independent variables. The results show that all factors have a positive significant influence on customer satisfaction, which leads to the electronic banking functionality factors has a positive influence on customer satisfaction in commercial banks in Jordan and also the customer satisfaction as mediation factor on the customers' loyalty and positive WOM.

Bogati (2016) identified the factors influencing the customer satisfaction and customer loyalty in the e-banking of the commercial banks in Thailand, considering seven factors which are Core service quality, Social benefits, Special treatment benefits, Confidence benefits, Physical benefits, Banking preferences, and Accessibility. By using 400 questionnaires, distributed on 206 e-banking clients, 194 traditional banking clients with 33 items each. A regression analysis applied to the collected primary data. The study revealed that 4 out of 9 variables which include (core service quality, social benefit, confidence benefits, and physical environment) have a significant positive contribution on the customer satisfaction, and up to $72 \%$ of the variance in customer satisfaction could be explained by these four independent variables.

Al-Otaibi et al. (2018) examined Saudi Arabian customers' satisfaction toward mobile banking in Saudi Arabia and the UK. Mobile banking is offering for the bank's customers to access their account anywhere anytime. The study used 100 online questionnaires, which was distributed for a sample of mobile banking users in both countries Saudi Arabia and the UK, considering three main factors: System quality, the information quality, and interface design. The system quality has a significant positive effect on customer satisfaction in the UK but not Saudi Arabia, the other two factors have a significant positive effect on customer satisfaction in both the UK and Saudi Arabia. In sum, British customers are more satisfied with mobile banking than Saudi Arabian customers.

Asfaw, F. (2017) studied the effect of electronic banking service quality on customer satisfaction in Ethiopia, the study applied both qualitative and quantitative research approaches, 100 questionnaires distributed to customers of commercial banks of Ethiopia, the collected data was analyzed using SPSS v20.0 The study finds that both service quality and the security of e-banking had been the significant factors on the satisfaction of the customers. There was a linear relationship between e-banking and customer satisfaction. The study recommended the community and the banks to enhance the level of awareness in using mobile and internet banking as forms of e-banking in Ethiopia.

Asiyanbi (2018) studied electronic banking impacts on customer satisfaction in Nigeria. The study tested two main hypotheses, one is related to the significance of Electronic banking effect on enhancing customer satisfaction and the other one is the adoption of electronic banking. The study applied a quantitative approach by distributing 100 questionnaires of the bank's customer in Ibadan Metropolis. The collected primary data analyzed using the SPSS v20.0 and resulted in high usage of the ATM and Internet banking with low usage of Bank transfer, POS, and Mobile Banking. The first hypothesis was accepted with the approved analysis that electronic banking significantly enhanced customer satisfaction. The second hypothesis was rejected but the approved analysis that high utilization of electronic banking reduced the branches visit frequency. In sum, increasing customer awareness is essential, to enhance the adoption and the usage of electronic banking in a way that increases customer satisfaction.

Ismail (2017) analyzed the impact of online banking as one of the electronic banking services on customer satisfaction in Jordan, considering the traditional banking effect on some people in developing countries. The study applied the quantitative approach in the analysis to find the relationship and impact of customer satisfaction. The survey was distributed among five selected banks in Jordan, and 100 questionnaires were considered and interviews were conducted in data analysis upon the completion.

In sum, the data analysis considered six main factors throughout this study (account access, account control, account use, cost and time effectiveness, easy to use and privacy \& security) were affected positively on satisfaction level of customer, when it comes to the Jordanian commercial banks, except for the privacy and security. As the client has some concerns regarding the security level while using online banking. Accordingly, contributing in a better quality of service and enhancing the awareness level of customers will increase the users of online banking, thus increasing online banking transactions, comparing to the traditional transactions and where the services are available and provided anywhere and anytime.

Consequently, reflecting all the stated literature and researchers above concluded. The study could conclude that 
none of them had conducted research on the E-Banking services impact on customer satisfaction in Palestine banking sector. Moreover, researchers considered the E-Banking strategies form the bank's Management point of view. These two observations created the "Knowledge gap" which will be covered in this research along with the theoretical framework, data analysis, and the study conclusion and the results will be explained later on.

\subsection{Palestine Banking Sector Overview}

Accordingly to Palestine Monetary Authority (2018): Palestine Monetary Authority (PMA) was established in 1997. PMA is considered the Central bank of Palestine which is responsible for regulating the banking sector and stabilizing the financial situation in Palestine.

All Banks that opened before and after 1994 were licensed by the (PMA). By the end of June 201, PMA statistics showed that they have 14 officially registered banks in Palestine. All are providing banking services in the West Bank and Gaza Strip through branches network and also through Electronic banking services, which include Automatic Teller Machines (ATM), Internet Banking, Mobile Banking, and Phone Banking, in diffident level as shown in Table 1.

Table 1. Banks usage of Electronic Banking

\begin{tabular}{|c|c|c|c|c|}
\hline Bank Name & $\begin{array}{l}\text { Mobile Banking } \\
\text { (MB) }\end{array}$ & $\begin{array}{l}\text { Internet Banking } \\
\text { (IB) }\end{array}$ & $\begin{array}{l}\text { Phone Banking } \\
\text { (PB) }\end{array}$ & $\begin{array}{c}\text { Automatic Teller Machine } \\
\text { ATM/BNA }\end{array}$ \\
\hline \multicolumn{5}{|c|}{ Foreign Banks } \\
\hline ARAB BANK & $\sqrt{ }$ & $\sqrt{ }$ & $\sqrt{ }$ & $\sqrt{ }$ \\
\hline CAIRO AMMAN BANK & $\sqrt{ }$ & $\sqrt{ }$ & $\sqrt{ }$ & $\sqrt{ }$ \\
\hline BANKF OR JORDAN & $\mathrm{X}$ & $\sqrt{ }$ & $\mathrm{X}$ & $\sqrt{ }$ \\
\hline JORDAN COMMERCIAL BANK & $\sqrt{ }$ & $\sqrt{ }$ & $\mathrm{X}$ & $\sqrt{ }$ \\
\hline HOUSING BANK & $\mathrm{X}$ & $\sqrt{ }$ & $\mathrm{X}$ & $\sqrt{ }$ \\
\hline JORDAN AHLI BANK & $\mathrm{X}$ & $\sqrt{ }$ & $\mathrm{X}$ & $\sqrt{ }$ \\
\hline EGYPTIAN ARAB LAND BANK & $\sqrt{ }$ & $\sqrt{ }$ & $\mathrm{X}$ & $\sqrt{ }$ \\
\hline \multicolumn{5}{|c|}{ Local Banks } \\
\hline BANK OF PALESTINE & $\sqrt{ }$ & $\sqrt{ }$ & $\sqrt{ }$ & $\sqrt{ }$ \\
\hline THE NATIONAL BANKS & $\sqrt{ }$ & $\sqrt{ }$ & $\mathrm{X}$ & $\sqrt{ }$ \\
\hline QUDS BANK & $\sqrt{ }$ & $\sqrt{ }$ & $\sqrt{ }$ & $\sqrt{ }$ \\
\hline PALESTINE ISLAMIC BANK & $\sqrt{ }$ & $\sqrt{ }$ & $\mathrm{X}$ & $\sqrt{ }$ \\
\hline PALESTINE INVESTMENT BANK & $\mathrm{X}$ & $\sqrt{ }$ & $\mathrm{X}$ & $\sqrt{ }$ \\
\hline ARAB ISLAMIC BANK & $\sqrt{ }$ & $\sqrt{ }$ & $\mathrm{X}$ & $\sqrt{ }$ \\
\hline SAFA BANK & $\sqrt{ }$ & $\sqrt{ }$ & $\mathrm{X}$ & $\sqrt{ }$ \\
\hline
\end{tabular}

www.pma.ps (2018)

Both Branches and ATMs numbers are growing over the years in Palestine, Figures 1 and 2 show the progress from Dec-2010 until Dec-2017 based on PMA (2018) statistics.

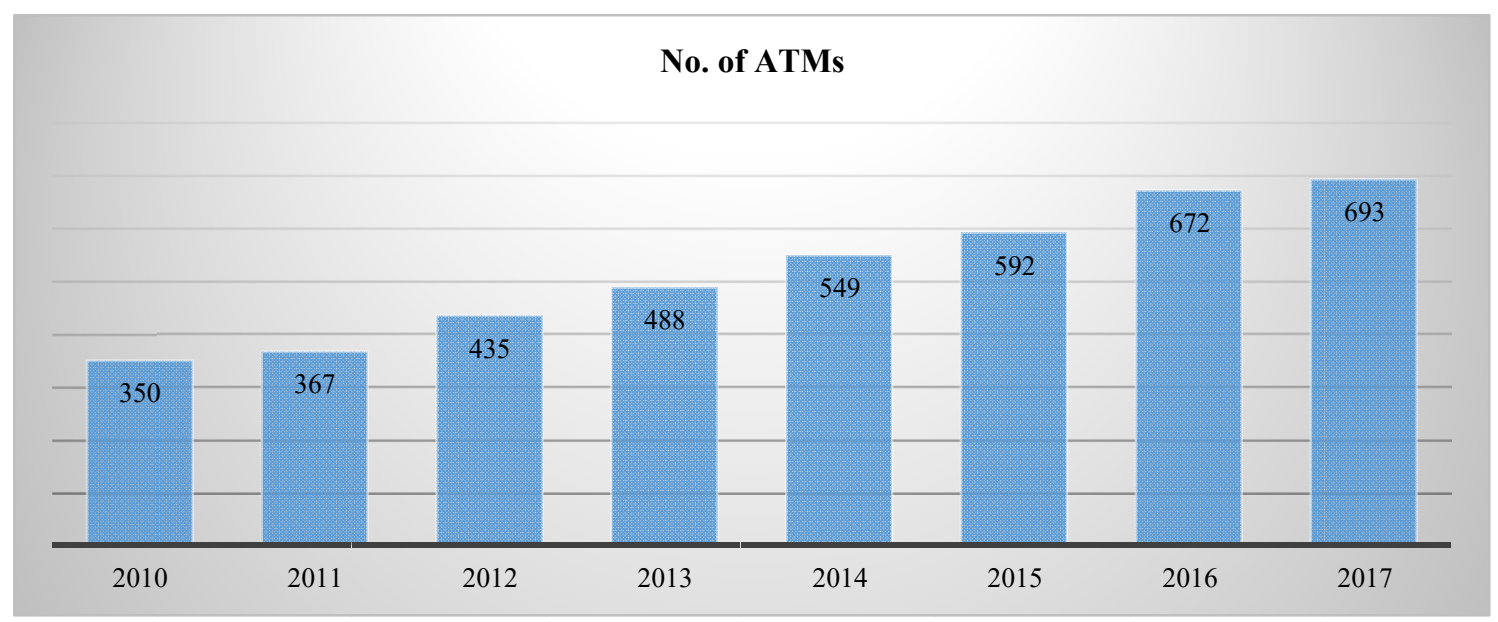

Figure 1. Palestine Banks’ ATMs network, www.abp.ps (2018) 


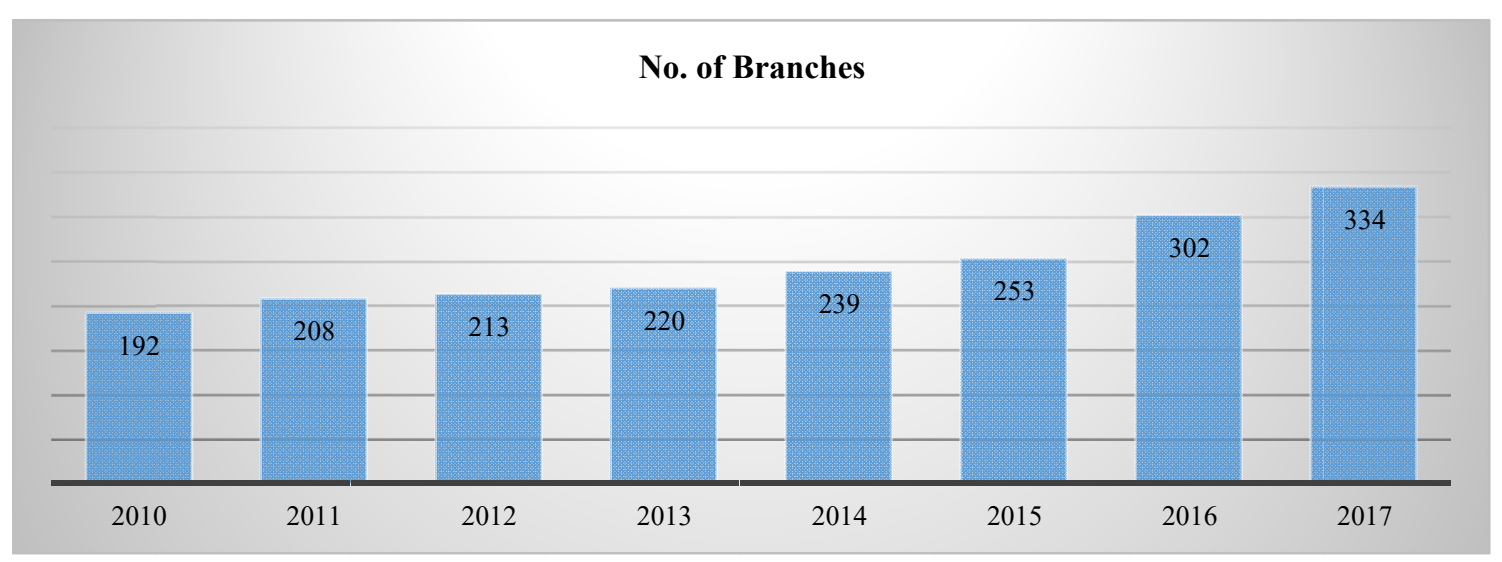

Figures 2. Palestine Banks' Branches Network, www.apb.ps (2018)

The number of customers and accounts are increasing over the years. Table 2 demonstrates the increase from the period of Dec.2010 until Sept. 2018 (The Palestine Monetary Authority 2018). It shows an increase in the number of customers by $14 \%$ and the number of banking accounts increased by $58 \%$, as clarified in Table 2 .

Table 2. The banking accounts and customers as data reporting for PMA

\begin{tabular}{cccccccccc}
\hline \multirow{2}{*}{ Banking Sector } & \multicolumn{1}{c}{ Years } \\
\cline { 2 - 9 } & 2010 & 2011 & 2012 & 2013 & 2014 & 2015 & 2016 & 2017 & Sep-18 \\
\hline No. of banking accounts (,000) & 2,186 & 2,543 & 2,715 & 2,748 & 2,767 & 2,941 & 3,099 & 3,209 & 3,457 \\
YTY Growth & & $16 \%$ & $7 \%$ & $1 \%$ & $1 \%$ & $6 \%$ & $5 \%$ & $4 \%$ & $8 \%$ \\
No. of Customers (,000) & 1,414 & 1,416 & 1,464 & 1,435 & 1,467 & 1,460 & 1,536 & 1,604 & 1,618 \\
YTY Growth & & $0 \%$ & $3 \%$ & $-2 \%$ & $2 \%$ & $0 \%$ & $5 \%$ & $4 \%$ & $1 \%$ \\
No. of Debit Card (VE) (,000) & \multirow{2}{*}{381} & 456 & 533 & 541 & 583 & 656 & 713 & 841 & 890 \\
& & $20 \%$ & $17 \%$ & $2 \%$ & $8 \%$ & $13 \%$ & $9 \%$ & $18 \%$ & $6 \%$ \\
\hline
\end{tabular}

www.pma.ps (2018)

\section{Theoretical Framework}

This chapter covers the research methodology, Questionnaire design and the Population and sample size that will try to answer the research question and test the research hypotheses related to e-banking and the impact on customer satisfaction.

\subsection{The Study Methodology}

The study methodology contains two main sections, a questionnaire, and interviews as will be clarified next:

\subsubsection{The Questionnaire}

The questionnaire aims at measuring the level of customer's satisfaction toward the electronic banking services introduced by the banks in Palestine from one hand and how much are they satisfied by these services form another hand. The questionnaire targeted the bank's customers a total of 347 participants in order to be able to measure their perspective regarding the customers' adoption and satisfaction also.

The questionnaire is developed to include two mains sections:

- Section one contains the Personal and Demographic Data of the sample population includes seven parameters or control variables (Gender, Marital status, Age in Years, Profession, Education Level, Annual Income in USD and the Address) as personal information and another 5 questions for the banking relationship.

- Section two contains six main parameters which are (Easy to use, Reliability, Information Security \& the Privacy, Cost \& Fees, and Availability) to measure how satisfied are the customers in using these electronic services? The sixth parameter is the customer satisfaction level toward the E-Banking services. with five questions for each parameter designed to measure the adoption level of customers regarding the electronic banking services introduced by banks in Palestine listed below:

1. Automatic Teller Machine (ATM)

2. Internet Banking (IB)

3. Mobile banking (MB) 


\section{Phone Banking (PB)}

The questionnaire is designed using 7 points of Likert scale (Ranged between strongly agree represented by \#7 and strongly disagree represented by \#1). The data analyzed using SPSS v25. Both Correlation and Regression analysis on the collected primary data to have a model of customer satisfaction as the dependent variable and how the electronic banking five main elements are effects on as independent variables. That will be explained in details in Chapter 4 (Data Analysis and findings)

\subsubsection{The Interviews}

The qualitative approach applies to two selected banks in Palestine listed below:

- Arab Bank / Mr. Jamal Hurani - Country Manager

- Bank of Palestine | Mr. Hasan Afifi - VP Head of IT

Five main questions designed for the interview with each bank's Management to explore their strategies, overview, and trends E-Banking services that will be clarified in details in the interviews results section (4.2)

\subsection{Population and Sampling}

The study population is the banks' customers in the Palestine banks mentioned in below Table 5 those having one of the Electronic banking services from their bank and using it. The sample includes 347 customers who participated in filling the questionnaire out of 450 questionnaires distributed on selected banks in Palestine that were targeted in the study:

Table 5. The Targeted Banks in the Sample

\begin{tabular}{cc}
\hline Local Banks & Foreign Banks \\
\hline Bank of Palestine & Arab Bank \\
Quds Bank & Cairo Amman Bank \\
The National Bank & Bank of Jordan \\
Palestine Investment Bank & Housing bank \\
Palestine Islamic bank & Jordan Commercial Bank \\
Arab Islamic Bank & Jordan Ahli Bank \\
Safa Bank & The Egyptian Arab Land Bank \\
\hline
\end{tabular}

www.pma.ps (2018)

\subsection{Study Design}

The study depended on a research model, which includes five main variables influencing on the customer's satisfaction level:

1. Easy to use.

2. Reliability.

3. Information Security \& Privacy.

4. Cost \& Fees.

5. Availability.

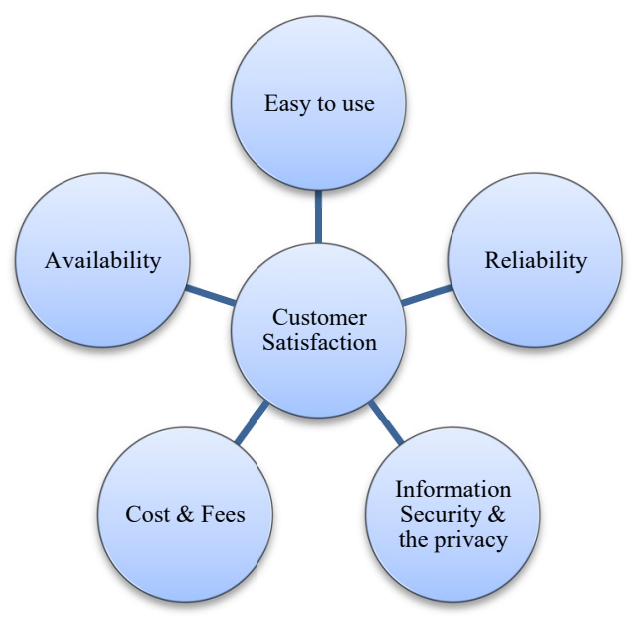

Illustration 1 . The 5 variables that have to influence power over customer's satisfaction 
This design was applied to measure the customer's satisfaction towards the four main Electronic banking services:

1. Automatic Teller Machine (ATM)

2. Internet Banking (IB).

3. Mobile banking (MB).

4. Phone Banking (PB).

The primary data will be collected from eight banks working in Palestine, under the umbrella of Palestine Monetary Authority (PMA), targeting the bank's customers and management.

\section{Data Analysis and Findings}

\subsection{Data Analysis Results}

During the sampling 8 banks out of 14 accepted to take the questionnaires, to be distributed to their customers, the total number of questionnaires 347 from the customers of 8 banks in Palestine, and they are:

Table 6. The 8 Banks that provided their customers with questionnaires

\begin{tabular}{lcccc}
\hline$\#$ & Bank's Name & No. of distributed questionnaires & No. of received questionnaires & Response $\%$ \\
\hline 1 & Arab Bank & 90 & 80 & $89 \%$ \\
2 & Arab Islamic Bank & 50 & 42 & $84 \%$ \\
3 & Ahli Jordan Bank & 50 & 28 & $56 \%$ \\
4 & Jordan Commercial bank & 50 & 29 & $58 \%$ \\
5 & Quds Bank & 50 & 41 & $82 \%$ \\
6 & Bank of Palestine & 90 & 81 & $90 \%$ \\
7 & Safa Bank & 50 & 31 & $62 \%$ \\
8 & The National Bank & 20 & 15 & $\mathbf{7 5 \%}$ \\
& Total & $\mathbf{4 5 0}$ & $\mathbf{3 4 7}$ & $\mathbf{7 7 \%}$ \\
\hline
\end{tabular}

In this section, the collected data will be analyzed to have results that will reflect a clear overview of the sample population:

\subsubsection{Correlation Analysis:}

The correlation analysis will be explaining the relationship between two or more variables, regarding the correlation coefficient value and its direction of relationship with positive or negative. The primary collected data includes 5 independent variables (IV) (Easiness of use, Availability, Information Security \& the privacy, Cost \& Fees, and Reliability) and one Dependent variable (DV) which is Customer satisfaction.

Referring to the below table (19), Each (IV) is moderately positively correlated with another independent variable, and all the relationships between them are significant as the value is $(0.000)$ less than $(0.05)$.

The (DV) (Customer satisfaction) is a moderately positively correlated with other five independent variables with coefficient correlation values $0.542,0.488,0.518,0.505$, and 0.684 with independent variables Easiness of use, Reliability, Information Security \& the privacy, Cost \& Fees and Availability respectively.

Table 7. The Correlation of (IV) and (DV)

\begin{tabular}{|c|c|c|c|c|c|c|c|}
\hline \multicolumn{8}{|c|}{ Correlations } \\
\hline & & $\begin{array}{c}\text { Easy to } \\
\text { use }\end{array}$ & Reliability & $\begin{array}{c}\text { Information Security \& } \\
\text { the Privacy }\end{array}$ & $\begin{array}{c}\text { Cost \& } \\
\text { Fees }\end{array}$ & Availability & $\begin{array}{c}\text { Customer } \\
\text { Satisfaction }\end{array}$ \\
\hline \multirow{3}{*}{ Easy to use } & Pearson Correlation & 1 & & & & & \\
\hline & Sig. (2-tailed) & & & & & & \\
\hline & $\mathrm{N}$ & 347 & & & & & \\
\hline \multirow{3}{*}{ Reliability } & Pearson Correlation & $.623^{* *}$ & 1 & & & & \\
\hline & Sig. (2-tailed) & .000 & & & & & \\
\hline & $\mathrm{N}$ & 347 & 347 & & & & \\
\hline Information & Pearson Correlation & $.577^{* *}$ & $.518^{* *}$ & 1 & & & \\
\hline Security \& the & Sig. (2-tailed) & .000 & .000 & & & & \\
\hline Privacy & $\mathrm{N}$ & 347 & 347 & 347 & & & \\
\hline Cost \& Fees & Pearson Correlation & $.422^{* *}$ & $.443^{* *}$ & $.525^{* *}$ & 1 & & \\
\hline
\end{tabular}




\begin{tabular}{cccccccc}
\hline & Sig. (2-tailed) & .000 & .000 & .000 & & \\
& $\mathrm{~N}$ & 347 & 347 & 347 & 347 & \\
& Pearson Correlation & $.482^{* *}$ & $.481^{* *}$ & $.442^{* *}$ & $.553^{* *}$ & 1 & \\
Availability & Sig. (2-tailed) & .000 & .000 & .000 & .000 & & \\
& $\mathrm{~N}$ & 347 & 347 & 347 & 347 & 347 & \\
Customer & Pearson Correlation & $.542^{* *}$ & $.488^{* *}$ & $.518^{* *}$ & $.505^{* *}$ & $.684^{* *}$ & 1 \\
Satisfaction & Sig. (2-tailed) & .000 & .000 & .000 & .000 & .000 & 347 \\
\hline **. Correlation is significant at the 0.01 level (2-tailed). & $\mathrm{N}$ & 347 & 347 & 347 & 347 & 347 \\
\hline
\end{tabular}

In order to analyze the coefficient of determination between the dependent variable and the other five independent variables, the study used $\mathrm{R}^{2}$ values.

Table 8. The Correlation of (IV) and (DV)

\begin{tabular}{cccccccc}
\hline & & $\begin{array}{c}\text { Easy } \\
\text { to use }\end{array}$ & Availability & $\begin{array}{c}\text { Information } \\
\text { Security \& the } \\
\text { Privacy }\end{array}$ & $\begin{array}{c}\text { Cost \& } \\
\text { Fees }\end{array}$ & Reliability & $\begin{array}{c}\text { Customer } \\
\text { Satisfaction }\end{array}$ \\
\hline $\begin{array}{c}\text { Customer } \\
\text { Satisfaction }\end{array}$ & $\begin{array}{c}\text { Pearson } \\
\text { Correlation } \\
\text { Coefficient of } \\
\text { Determination }\left(\mathrm{r}^{2}\right)\end{array}$ & 0.538 & 0.685 & 0.516 & 0.502 & 0.485 & 1.000 \\
\hline
\end{tabular}

- $28.9 \%$ of the variance in (DV) customer satisfaction has been explained by Easiness of use independent variable.

- $46.9 \%$ of the variance in (DV) customer satisfaction has been explained by Availability independent variable.

- $26.6 \%$ of the variance in (DV) customer satisfaction has been explained by Information Security and Privacy independent variable.

- $25.2 \%$ of the variance in (DV) customer satisfaction has been explained by the cost and fees independent variable.

- $23.5 \%$ of the variance in (DV) customer satisfaction has been explained by the reliability independent variable.

\subsubsection{Regression Analysis}

The study uses a regression model to examine the dependency of dependent variables (Customer satisfaction) on other five independent variables (Easy to use, Reliability, Information security and Privacy, Cost and fees and the availability). The analysis will consider each one of the independent variable and the relationship with the dependent variable.

1. Easy to Use regression model

Table 9. The easy to use regression model

\begin{tabular}{|c|c|c|c|c|c|c|c|}
\hline \multicolumn{8}{|c|}{ Model Summary } \\
\hline \multirow{2}{*}{ Model } & \multirow{2}{*}{$\mathrm{R}$} & \multirow{2}{*}{ R Square } & \multirow{2}{*}{ Adjusted R Square } & \multirow{2}{*}{ Std. Error of the Estimate } & \multicolumn{3}{|c|}{ Change Statistics } \\
\hline & & & & & R Square Change & F Change df1 df2 & Sig. F Change \\
\hline 1 & $.542^{\mathrm{a}}$ & .294 & .292 & .68313 & .294 & $143.695 \quad 1 \quad 345$ & .000 \\
\hline
\end{tabular}

a. Predictors: (Constant), Easy to use

In other words, 0.292 of changes in Customer satisfaction is attributes to Easy to use IV.

Table 10. The easy to use regression Coefficient

\begin{tabular}{|c|c|c|c|c|c|c|}
\hline \multicolumn{7}{|c|}{ Coefficients $^{\mathrm{a}}$} \\
\hline & \multirow{2}{*}{ Model } & \multicolumn{2}{|c|}{ Unstandardized Coefficients } & \multirow{2}{*}{$\begin{array}{c}\text { Standardized Coefficients } \\
\text { Beta }\end{array}$} & \multirow{2}{*}{$\mathrm{t}$} & \multirow{2}{*}{ Sig. } \\
\hline & & B & Std. Error & & & \\
\hline \multirow{2}{*}{1} & (Constant) & 2.642 & .281 & & 9.386 & .000 \\
\hline & Easy to use & .555 & .046 & .542 & 11.987 & .000 \\
\hline
\end{tabular}

a. Dependent Variable: Customer Satisfaction 
The model equation will be:

$$
\text { DV }(\text { Customer satisfaction })=\mathrm{B}_{0}+\mathrm{b}_{1} \mathrm{X}_{1}
$$

As:

- $\mathrm{B}_{0}=2.642$

- $\mathrm{b}_{1}=0.555$

- $\mathrm{X}_{1}=$ Easy to use

2. Reliability regression model

Table 11 . The Reliability regression model

\begin{tabular}{|c|c|c|c|c|c|c|c|}
\hline \multicolumn{8}{|c|}{ Model Summary } \\
\hline \multirow{2}{*}{ Model } & \multirow{2}{*}{$\mathrm{R}$} & \multirow{2}{*}{ R Square } & \multirow{2}{*}{ Adjusted R Square } & \multirow{2}{*}{ Std. Error of the Estimate } & \multicolumn{3}{|c|}{ Change Statistics } \\
\hline & & & & & R Square Change & F Change df1 df 2 & Sig. F Change \\
\hline 1 & $.488^{\mathrm{a}}$ & .238 & .235 & .70987 & .238 & $107.580 \quad 1 \quad 345$ & .000 \\
\hline
\end{tabular}

a. Predictors: (Constant), Reliability

In other words, 0.235 of changes in Customer satisfaction is attributed to Reliability IV.

Table 12. The Reliability Regression Coefficient

\begin{tabular}{|c|c|c|c|c|c|c|}
\hline \multicolumn{7}{|c|}{ Coefficients $^{\mathrm{a}}$} \\
\hline & \multirow{2}{*}{ Model } & \multicolumn{2}{|c|}{ Unstandardized Coefficients } & \multirow{2}{*}{$\begin{array}{c}\text { Standardized Coefficients } \\
\text { Beta }\end{array}$} & \multirow{2}{*}{$\mathrm{t}$} & \multirow{2}{*}{ Sig. } \\
\hline & & B & Std. Error & & & \\
\hline \multirow{2}{*}{1} & (Constant) & 3.296 & .262 & & 12.569 & .000 \\
\hline & Reliability & .455 & .044 & .488 & 10.372 & .000 \\
\hline
\end{tabular}

a. Dependent Variable: Customer Satisfaction

The model equation will be:

$$
\text { DV }(\text { Customer satisfaction })=B_{0}+b_{1} X_{1}
$$

As:

- $\mathrm{B}_{0}=3.296$

- $\mathrm{b}_{1}=0.455$

- $\mathrm{X}_{1}=$ Reliability

3. Information security and Privacy regression model

\begin{tabular}{|c|c|c|c|c|c|c|c|}
\hline \multicolumn{8}{|c|}{ Model Summary } \\
\hline \multirow{2}{*}{ Model } & \multirow{2}{*}{$\mathrm{R}$} & \multirow{2}{*}{ R Square } & \multirow{2}{*}{ Adjusted R Square } & \multirow{2}{*}{ Std. Error of the Estimate } & \multicolumn{3}{|c|}{ Change Statistics } \\
\hline & & & & & R Square Change & F Change df1 df2 & Sig. F Change \\
\hline 1 & $.488^{\mathrm{a}}$ & .238 & .235 & .70987 & .238 & $107.580 \quad 1 \quad 345$ & .000 \\
\hline
\end{tabular}

Table 13. The Information security and Privacy regression model

Predictors: (Constant), Reliability

In other words, 0.235 of changes in Customer satisfaction is attributed to Information security and Privacy IV.

\begin{tabular}{|c|c|c|c|c|c|c|}
\hline \multicolumn{7}{|c|}{ Coefficients $^{\mathrm{a}}$} \\
\hline & \multirow{2}{*}{ Model } & \multicolumn{2}{|c|}{ Unstandardized Coefficients } & \multirow{2}{*}{$\frac{\text { Standardized Coefficients }}{\text { Beta }}$} & \multirow{2}{*}{$\mathrm{t}$} & \multirow{2}{*}{ Sig. } \\
\hline & & B & Std. Error & & & \\
\hline \multirow{2}{*}{1} & (Constant) & 2.670 & .297 & & 8.977 & .000 \\
\hline & Information Security \& the Privacy & .548 & .049 & .518 & 11.243 & .000 \\
\hline
\end{tabular}

Table 14. The Information security and Privacy Regression Coefficient

a. Dependent Variable: Customer Satisfaction

The model equation will be:

DV $($ Customer satisfaction $)=\mathrm{B}_{0}+\mathrm{b}_{1} \mathrm{X}_{1}$ 
As:

- $\mathrm{B}_{0}=2.67$

- $\mathrm{b}_{1}=0.548$

- $\quad \mathrm{X}_{1}=$ Information security and Privacy

4. Cost and Fees regression model

Table 15. The Cost and Fees regression model

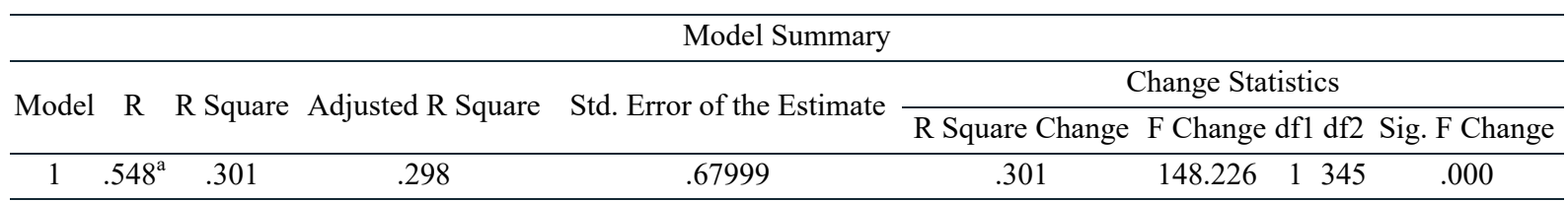

a. Predictors: (Constant), Cost \& Fees

In other words, 0.298 of changes in Customer satisfaction is attributed to the cost and fees IV.

Table 16. Cost and Feed Regression Coefficient

\begin{tabular}{ccccccc}
\hline & \multicolumn{5}{c}{ Coefficients $^{\mathrm{a}}$} \\
\hline \multirow{2}{*}{ Model } & \multicolumn{2}{c}{ Unstandardized Coefficients } & Standardized Coefficients & \multirow{2}{*}{ S } \\
\cline { 3 - 6 } & & $\mathrm{B}$ & Std. Error & Beta & \\
\hline \multirow{2}{*}{1} & (Constant) & 3.482 & .209 & & 16.663 & .000 \\
& Cost \& Fees & .445 & .037 & .548 & 12.175 & .000 \\
\hline
\end{tabular}

a. Dependent Variable: Customer Satisfaction

The model equation will be:

DV $($ Customer satisfaction $)=\mathrm{B}_{0}+\mathrm{b}_{1} \mathrm{X}_{1}$

As:

- $\mathrm{B}_{0}=3.482$

- $\mathrm{b}_{1}=0.445$

- $\mathrm{X}_{1}=$ Cost and fees

5. The Availability regression model

Table 17. The Availability regression model

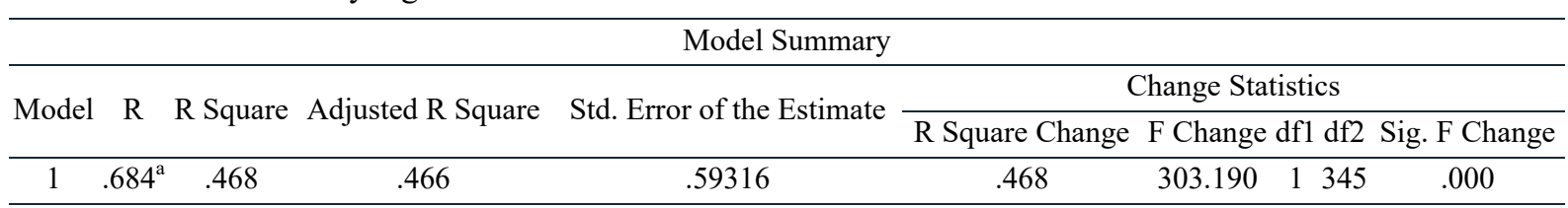

a. Predictors: (Constant), Availability

In other words, 0.466 of changes in Customer satisfaction is attributed to the availability as IV.

Table 18. The Availability Regression Coefficient

\begin{tabular}{|c|c|c|c|c|c|c|}
\hline \multicolumn{7}{|c|}{ Coefficients $^{\mathrm{a}}$} \\
\hline & \multirow{2}{*}{ Model } & \multicolumn{2}{|c|}{ Unstandardized Coefficients } & \multirow{2}{*}{$\begin{array}{c}\text { Standardized Coefficients } \\
\text { Beta }\end{array}$} & \multirow{2}{*}{$\mathrm{t}$} & \multirow{2}{*}{ Sig. } \\
\hline & & B & Std. Error & & & \\
\hline \multirow{2}{*}{1} & (Constant) & 2.534 & .201 & & 12.617 & .000 \\
\hline & Availability & .585 & .034 & .684 & 17.412 & .000 \\
\hline
\end{tabular}

a. Dependent Variable: Customer Satisfaction

The model equation will be:

$$
\text { DV }(\text { Customer satisfaction })=B_{0}+b_{1} X_{1}
$$

As: 
- $\quad \mathrm{B}_{0}=2.534$

- $\mathrm{b}_{1}=0.585$

- $\mathrm{X}_{1}=$ The Availabilty.

All the five independent variables have a significant relationship with DV ( customer satisfaction) as the P-value for all of them are 0.000 , which is less than 0.05

Upon the Correlation and Simple Regression analysis for each independent variables, the study finds:

- The Participants are satisfied with the E-Banking services in Palestine as the average of their feedback within "Agree" and "strongly agree", thus the study null hypothesis $\left(\mathbf{H}_{\mathbf{0}}\right)$ was rejected and the study alternative hypothesis $\left(\mathbf{H}_{\mathbf{1}}\right)$ was accepted, and there is a significant positive impact of the electronic banking on the customers' satisfaction.

- $\quad$ Regarding the sub-hypotheses: $\mathbf{H}_{\mathbf{1 - 1}}, \mathbf{H}_{\mathbf{1 - 2}}, \mathbf{H}_{\mathbf{1 - 3}}, \mathbf{H}_{\mathbf{1 - 4}}$, and $\mathbf{H}_{\mathbf{1 - 5}}$ were accepted while

$\mathbf{H}_{1-1:}$ Easy to use of Electronic Banking has a significant positive effect on customer satisfaction.

$\mathbf{H}_{1-2}$ : Reliable Electronic Banking has a significant positive effect on customer satisfaction.

$\mathbf{H}_{1-3:}$ Electronic banking Information security and privacy have a significant positive effect on customer satisfaction.

$\mathbf{H}_{1-4}$ : Electronic banking cost and fees have a significant positive effect on customer satisfaction.

$\mathbf{H}_{1-5:}$ : Electronic banking availability has a significant positive effect on customer satisfaction.

\subsection{The Interviews Results}

interviews conducted with selected two banks Management in Palestine, those are the Arab bank and Bank of Palestine. Both banks have their own strategy regarding E-Banking services. In this section, the five main questions that were asked for the banks will be analyzed to anticipate the future of E-Banking services and the relationship with customers' satisfaction from the Banks' management perspective

\section{What are the bank's Five-year approach and Plan towards integrating the electronic banking services?}

Arab bank is considered a big bank, seeking to be the leading bank in the Arab World in financial technology from one side and Policies and procedures on another side. The bank is introducing the Electronic banking services to their customers based on a strategic plan combining the advancement in communication, database, systems, and technology. Arab Bank is introducing many E-Banking services including Automatic Teller Machine, Internet Banking, Mobile Banking and Phone Banking with many banking services inside each of them that allow the customer to execute a number of different banking transactions anywhere and anytime.

The key in developing the E-Banking services is the satisfaction and the experience of the end-users, the bank is looking for continuous enhancing and expanding the E-Banking services horizontally and vertically considering all the local and global constraints related to the legal, laws and regulations, putting the customer trust as the top priority.

Bank of Palestine is also offering wide E-Banking services for their customers and working on enhancing and increasing them based on the Plan. The bank believes that such services are improving the overall service level for the bank toward their customers by saving their time and efforts and making the banking services easier and available.

Bank of Palestine has an advanced experience in Payments services also such as the Point of Sales (POS) and Payment gateways in addition of the E-Banking services includes ATM, IB, MB and PB that are offering for individuals customers now, and will be for the corporate customers in the future. The more the customers are being trusted and aware of this service the more adoption and usage level.

The bank is also looking for integrating the government services with financial services for better customers experience and comprehensive banking solutions, which requires an investment from the Palestinian government in the E-services and E-Government involving all related stakeholders.

\section{What are the main reasons behind this approach?}

Arab Bank believes that E-Banking strategies and services are essential for many reasons most of them are related to the customers, includes enabling the bank to continue and survive in the banking industry by address the advancement and the changes in this sector for better performance, cost efficiency and best use of the 
resources, specially the digital banking services and systems. Also enabling the bank to target new Market and reaching new customers those looking for an advanced banking solutions and services represented by E-Banking services, this is not limited for new customers only but existing customers' needs are changing over time and the bank has to meet such needs on time and may direct that needs for better service level and customers' satisfaction. What is acceptable 10 years ago is no longer now.

Bank of Palestine trusted that the customer needs the E-Banking services to access and use the banking services anywhere and anytime, this is becoming essential for customers and should be met. In a way that the bank's management is fully aware of the importance of E-Banking services in customers' satisfaction. The E-Banking is also contributing to reducing the cost and increasing the efficiency. E-banking services putting the bank on a global level not local, that pushing the bank for continues improvement the banking services, investing in technology, and advance the customer experience to survive, improve and increase the market share.

3. How was the impact of the Palestinian environment (Infrastructure, Human Power, Technology and systems) with the electronic banking adoption and usage by the customers?

Arab Bank concluded that Palestine infrastructure related to the telecommunications (Landline and third generation of the wireless connection ( $3 \mathrm{G})$ is an efficient but continuous improvement is a must, $3 \mathrm{G}$ is motivating the applications and usage of E-Banking services.

The technology and systems are advanced as most of them are a global system, The FinTech could be a local alternative if compliance with all requirements and conditions related to the regulations, privacy, and trust. Human power education level is acceptable, but more efforts are required to minimize the gap within the workplace.

Arab Bank is working on moving its customers from conventional banking through the branches to E-Banking services by introducing the orientation and awareness sessions to make them feel trust. The prizes and campaigns are a good tool to motivate the customers in using the E-Baking services. The customers also need to feel in a high level of security and privacy in E-Banking.

Bank of Palestine considered the Palestine infrastructure is old as the $3 \mathrm{G}$ had been launched in Palestine since a year or more while the developed countries are going for the 5G technology. Regarding the graduate students, there is a big gap between the Knowledge in academic and workplace, more efforts are required to reduce this gap by enhancing the student's skills and interact with the environment during the education period.

Customer awareness is an essential driver for E-Banking services usage and satisfaction level, but more and more programs and campaigns are needed to increase such awareness in all customer segments.

\section{Do you think that the customers' satisfaction toward electronic banking services is more than the} traditional bank's branches services? And why?

Arab Bank thinks that there are two groups of customers, the $1^{\text {st }}$ is willing to have and use E-Banking services and will be happy in that upon their knowledge on the advantages of E-Banging services such as the accuracy, the control, the speed, and the availability, the $2^{\text {nd }}$ group is still using the traditional banking services and visiting the physical branches, therefore the bank need till the needs and wants of both group form one hand and investing increase the awareness and willingness of the 2 ng group to move the E-Banking services shorter. Accordingly, satisfying the E-Banking customers are critical to the success in this approach.

Bank of Palestine believes that increasing E-Banking customers' satisfaction is essential to encourage the traditional banking customer to move for E-Banking due to their advantages. People needs and behavior is changing over time. The people are being influenced by the advantages of technology in their life. So they will be happy in making life easier using the technology such as the E-Banking services, no delay, no waiting lines at banks, $24 / 7$ hours viability....etc. Of course, some people are still using the traditional banking services which are normal.

\section{From your point of view, what is the (PMA) role in supporting the bank's approach toward electronic banking? And what is needed for obtaining better outputs?}

Arab bank considered Palestine Monetary Authority (PMA) is the leading of E-banking and Digital banking, PMA is continuing supporting the bank and all the banking sector are appreciated. PMA is working with the bank to enhance the E-Banking and E-Payments in Palestine in a way that complied with all the related rules, regulations and standards such as Anti Money Laundry regulation (AML),

Also, PMA is responsible for enforcing all the banks to comply with the most advanced cybersecurity and privacy solutions in offering their E-Banking services. This will enhance the customer confidence and 
trustworthiness in E-Banking services, and accordingly increasing the usage by time.

Accordingly to Bank of Palestine, PMA has many projects together in advancing the E-banking services for the customers, PMA launched the National Switch 194 Project that connected all Banks ATMs together in one local network and a way that increase the efficiency of use of these ATM and reduces the cost on all banks customers. Now, the bank and PMA is working with a similar project but of Point of Sales (POS

PMA considered the E-Banking services are one of the financial inclusion drivers. PMA is supporting the bank in enhancing the legal and regulations related to the E-Banking for protecting the customers and the bank.

Cooperation of all primary stakeholders (PMA, the banks, and the Palestinian government) in leading the E-banking services and integrating them with government services, will be improving the customer experience and increase their satisfaction.

\section{Study Conclusion \& Recommendation}

This is the final section of the study, which includes: the study conclusion results, and the recommendation for the interested people and researchers.

\subsection{Conclusion}

E-Banking services became essential channels for all banks to survive and compete in Palestine. This is supported by the banks E-Banking strategies and plans explained in the interviews with two of the top banks in Palestine (Arab bank and Bank of Palestine), Both banks had implemented E-Banking strategies in the past and have new strategies for the future to go deeply in E-Banking services and digital banking for enhancing the customers' experience and satisfaction, focusing on the coming new generation.

There are directions from some banks in Palestine to expand their E-Banking services horizontally by adding more E-banking channels similar to mobile banking and internet banking. And to expand vertically also by increasing the banking services in each channel such as payments, transfers, account management ...etc., to make more and more banking services available for the customers away from the physical branches.

It seems there is an exchanged positive relationship between E-Banking strategies and Customer satisfaction. What does this mean? It means, the banks by offering E-Banking \& digital services for their customers, they are working to increase the customers' satisfaction toward them. On the other side, the customers are seeking E-Banking services to be more satisfied with the bank. In sum, E-Banking services became an important competitive advantage for the bank in the market.

\subsection{Recommendation}

The scope of this study has crucial importance in the banking sector in Palestine, studying the effects of the electronic banking services provided on the customers' satisfaction is a vital factor in the decision making process for the Palestinian Monetary Authority (PMA), Banks in Palestine, Palestinian Government, decision-makers, Academic people, and the students. The recommendations of this study are as follows:

- The advancement in technology is improving the banking sector performance, services, and enhance the efficiency in a way that all banks need to move in this approach and apply the E-Banking services to their customers to attract, keep and grow them.

- The Palestinian people are satisfied in their experience with E-banking services, but the banks have to focus more on the main variables considered in this study to enhance their customers' experience by including more banking services in the E-Banking such as account opening, more payment options, and credit facilities.

- One of the key point in E-Banking services in addition to improving the usage rate, is the service access, the more you make accessing the E-banking service is easier by the customers the more they have. Introducing the Smart Personal Identification Card (ID card) by the Palestinian government to the citizen with full integration with the banking sector.

- The PMA and the banks need to work on an awareness campaign on the E-banking includes how to get? How to use? What are the available services?

\section{References}

Addai, O., Ameyaw, B., Ashalley, E., \& Quaye, I. (2015). Electronic Banking and Customer Satisfaction: Empirical Evidence from Ghana. British Journal of Economics, Management \& Trade, 9(3), 1-8. https://doi.org/10.9734/BJEMT/2015/19269 
Ahmad, A. M. K., \& Al-Zu'bi, H. A. (2011). E-banking functionality and outcomes of customer satisfaction: an empirical investigation. International Journal of Marketing Studies, 3(1), 50. https://doi.org/10.5539/ijms.v3n1p50

AlHaliq, H. A., \& AlMuhirat, A. A. (2016). Customer satisfaction with electronic banking services in the Saudi banking sector. Asian Social Science, 12(5), 139. https://doi.org/10.5539/ass.v12n5p139

Al-Otaibi, S., Aljohani, N. R., Hoque, M. R., \& Alotaibi, F. S. (2018). The Satisfaction of Saudi Customers Toward Mobile Banking in Saudi Arabia and the United Kingdom. Journal of Global Information Management (JGIM), 26. https://doi.org/10.4018/JGIM.2018010105

AL-Zahrani, A. A., \& Almazari, A. A. (2015). The Impact of E-Banking on Employees Job Security.

Asfaw, F. (2017). The Effect of E-Banking Service Quality on Customer Satisfaction in The Banking Sector of Ethiopia (case study Five Selected Grade Four Branch Customers of CBE) (Doctoral dissertation, St. Mary's University).

Asiyanbi, H., \& Ishola, A. (2018). E-banking services impact and customer satisfaction in selected bank branches in Ibadan metropolis, Oyo state, Nigeria. Accounting, 4(4), 153-160. https://doi.org/10.5267/j.ac.2018.3.001

Bogati, D., \& Vongurai, R. (2016). Determinants of Customer Satisfaction and Customer Loyalty in E-Banking A Case Study of Thailand's Selected Commercial Banks in Bangkok's Central Business Area. International Research E-J.

Hill, N., \& Alexander, J. (2006). The Handbook of Customer Satisfaction and Loyalty Measurement. London: Routledge.

Hill, N., \& Brierley, J. (2017). How to measure customer satisfaction. Routledge. https://doi.org/10.4324/9781315253107

Ismail, L. B., \& Alawamleh, M. (2017). The Impact of Online Banking on Customer Satisfaction in Jordan. Journal of Organisational Studies and Innovation, 4(2), 1-13.

Keivani, F. S., Jouzbarkand, M., Khodadadi, M., \& Sourkouhi, Z. K. (2012). A General View on the E-banking. International Proceedings of Economics Development \& Research, 43.

Kotler, P., \& Keller, K. (1988). Marketing management. American Journal of Industrial and Business Management, 6(5), 12.

Ministry of Telecommunication and information technology. (2018). Retrieved from http://www.mtit.gov.ps/

Oh, H. (1999). Service quality, customer satisfaction, and customer value: A holistic perspective. International Journal of Hospitality Management, 18(1), 67-82. https://doi.org/10.1016/S0278-4319(98)00047-4

Ovia, J. (2005). Enhancing the efficiency of the payment system in Nigeria. CBN Bullion, 29(1), 8-18.

Palestinian Central Bureau of Statistics (PCBS). (2018). Retrieved from http://www.pcbs.gov.ps/

Raza, S. A., Jawaid, S. T., \& Hassan, A. (2015). Internet banking and customer satisfaction in Pakistan. Qualitative Research in Financial Markets, 7(1), 24-36. https://doi.org/10.1108/QRFM-09-2013-0027

The Association of Banks in Palestine (ASP). (2018). Retrieved from http://www.abp.ps/

The Palestine Monetary Authority (PMA). (2018). Retrieved from http://www.pma.ps/

Thulani, D., Tofara, C., \& Langton, R. (2015). Adoption and use of internet banking in Zimbabwe: An exploratory study. The Journal of Internet Banking and Commerce, 2009.

Yi, Y., \& Nataraajan, R. (2018). Customer satisfaction in Asia. Psychology \& Marketing, 35(6), 387-391. https://doi.org/10.1002/mar.21093

\section{Copyrights}

Copyright for this article is retained by the author(s), with first publication rights granted to the journal.

This is an open-access article distributed under the terms and conditions of the Creative Commons Attribution license (http://creativecommons.org/licenses/by/4.0/). 